\title{
Evaluation of Bacillus Strains Isolated from Doni River Belt of Vijayapura District for their Plant Growth Promotional Activity
}

\author{
Geeta Goudar*, G. Sreenivasulu and P.U. Krishnaraj \\ Department of Agriculture Microbiology, College of Agriculture, Vijayapura-586 101 \\ UAS Dharwad, India \\ *Corresponding author
}

\section{A B S T R A C T}

\section{Keywords}

Bacillus, PGPR,

Sorghum, P-

Solubilization,

Biochemical

characterization

\section{Article Info}

Accepted:

07 November 2018

Available Online:

10 December 2018
Study was conducted to isolate and analyse the plant growth promotional activity of Bacillus strains isolated from Doni river belt of Vijayapura district. Total of 30 isolates were obtained from 15 rhizosphere soil samples. Further all the isolates were subjected for P-solubilization efficiency. All the 30 isolates showed zone of solubilization on Pikovskaya's media. The zone of solubilization $(\mathrm{mm})$ ranged from 7.2 to $16.00 \mathrm{~mm}$ on the petriplate. The amount of Pi released in the media ranged of 4.7 to 13.70 per cent. Out of 30 isolates, only 10 isolates were positive for IAA and GA production. These thirty isolates were subjected for different morphological and biochemical studies. With respect to biochemical characterization, all the isolates showed positive for nitrate reduction, $\mathrm{V}-\mathrm{P}$ test and oxidase test and negative for acid and gas production, arginine hydrolysis, esterase activity and chitinase activity. Based on the ability of the isolates to solubilise inorganic phosphorous and IAA and GA production, ten of the isolates were taken for pot culture experiment using sorghum as test crop. Under pot culture experiment, the Bacillus strains KJ-1, DWH-1 and HS-1 performed better with respect to plant height, shoot and root dry matter of sorghum.

\section{Introduction}

Agriculture is heavily dependent on the use of chemical fertilizers and pesticides to achieve higher yields. This dependence is associated with the problems such as environmental pollution, health hazards, interruption of natural ecological nutrient cycling and destruction of biological communities that otherwise support crop production. Hence, crop production and pest and disease management have to be achieved in shorter intervals of time with fewer detrimental inputs. The use of bioresource to replace chemical fertilizers and pesticides is growing. In this context, plant growth promoting microorganisms are often novel and potential tools to provide substantial benefits to agriculture (Sivasakti et al., 2013). Plant Growth Promoting Rhizobacteria (PGPR) are microbes specially designed by nature that harbour growth promotional benefits for host plant. Strains with PGPR activity, belonging to genera Azoarcus, Azospirillum, 
Azotobacter, Arthrobacter, Bacillus, Clostridium, Enterobacter, Gluconacetobacter, Pseudomonas and Serratia (Hurek and Reinhold-Hurek, 2003). Among these, species of Pseudomonas and Bacillus are the most extensively studied. These bacteria competitively colonize the roots of plant and can act as biofertilizers and/or antagonists (biopesticides) or simultaneously both.

Diversified populations of aerobic endospore forming bacteria (AEFB), viz., species of Bacillus, occur in agricultural fields and contribute to crop productivity directly or indirectly. Physiological traits, such as multilayered cell wall, stress resistant endospore formation, and secretion of peptide antibiotics, peptide signal molecules, and extracellular enzymes, are ubiquitous to these bacilli and contribute to their survival under adverse environmental conditions for extended periods of time.

Multiple species of Bacillus and Paenibacillus are known to promote plant growth. The principal mechanisms of growth promotion include production of growth stimulating phytohormones, solubilization and mobilization of phosphate, siderophore production, antibiosis, i.e., production of antibiotics, inhibition of plant ethylene synthesis, and induction of plant systemic resistance to pathogens (Richardson et al., 2009; Idris et al., 2007; Gutierrez-Manero et al., 2001). It is very likely that plant growth promotion by rhizosphere bacilli may be a result of combined action of two or more of these mechanisms.

Plant growth promoting rhizobacteria which possess the enzyme, 1-aminocyclopropane-1carboxylate (ACC) deaminase, facilitate plant growth and development by decreasing ethylene levels, inducing salt tolerance and reducing drought stress in plants (Nadeem et al., 2007 and Zahir et al., 2008).
Plant growth promotion and biocontrol action is widely studied in Bacillus genera, a common inhabitant of rhizopshere (Wahyudi et al., 2011). Colonization of roots by PGPR is the seed to successful plant-microbe interaction. In certain associations of microbes with plants, exopolysaccharides (EPS) have a major role that help bacteria to inhabit the root surface through specific adhesion, leading to root colonization that eventually results in biofilm formation (Michiels et al., 1991; Matthysse et al., 2005; Ramey et al., 2004). In this context, systematic attempts were made to obtain the Bacillus strains from dry areas of Northern regions of Karnataka and their role in plant growth promotion was evaluated in Sorghum (Sorghum bicolor).

\section{Materials and Methods}

\section{Soil sample processing and isolation of soil bacilli}

Soil samples were collected from villages of doni river belt viz., Tikota bridge, Danyal, Kanmuchnal, Sarwad, Tonshyal, Dadamatti, Honaganahalli, Hittinahalli, Ukamanahal and Katnalli and sampling was done at the surface and subsurface using a sterile spatula. Soil samples were placed in sterile plastic bags. The soil was processed by removing all large particles and plant materials such as leaves. Each soil sample $(20 \mathrm{~g})$ was suspended with $20 \mathrm{ml}$ of sterile distilled water in a sterile bottle. Soil suspensions were vortexed and placed in a water bath with temperature adjusted to $100{ }^{\circ} \mathrm{C}$. Heat treatment of the soil suspensions was performed at $100{ }^{\circ} \mathrm{C}$ for 5 min with gentle shaking. After heat treatment, heat-treated soil suspensions were incubated at room temperature for $2 \mathrm{~h}$ and serially diluted prior to plating on LB agar for isolation of single colonies. Plates were incubated at $28^{\circ} \mathrm{C}$ for $16 \mathrm{~h}$. Pure colonies were obtained by repetitive dilution streaking. 


\section{Characterization of Bacillus isolates}

The isolates were studied for their colony morphology, cell shape and gram reaction as per the standard procedure given by Barthalomew and Mittewar (1950) and Anonymous (1957). The isolates were subjected to biochemical characterization by employing the standard procedures given by Cappuccino and Sherman (1992). Different biochemical tests performed were Starch Hydrolysis, Casein hydrolysis, Acid and gas production, Nitrate reduction, V-P reaction, Catalase test, Arginine hydrolysis, Esterase activity, Chitinase activity and Oxidase test.

\section{Functional characterization of FP isolates}

The isolates were tested for their ability to solubilize $\mathrm{P}$ and ability to produce plant growth promoting substances like IAA and GA.

Plant growth promotional activity of Bacillus strains on sorghum under pot culture condition

\section{Preparation of pots}

Red soil collected from the nearby fields of Vijayapura was mixed with sand and farm yard manure (4:1:1) and filled in to pots of 90 $\mathrm{cm}$ diameter at the rate of $6 \mathrm{~kg}$ per bag and were kept in a shade house.

\section{Fertilizer application}

The recommended dose of fertilizer for sorghum is $25: 50: 0 \mathrm{NPK} \mathrm{kg} / \mathrm{ha}$. A calculated quantity of urea was applied on soil weight basis after sowing Bacillus treated sorghum seeds. Since the isolates are known to solubilise inorganic phosphorous, so $\mathrm{P}$ was given as rock phosphate. The observations were recorded for plant growth parameters.

\section{Results and Discussion}

A total of 15 soil samples were collected and subjected for the isolation of Bacillus using heat treatment method. Total of 30 isolates were obtained from 15 soil samples. Use of heat treatment method for the isolation of Bacillus species from soil sample has been suggested by Chan et al., (2007), Khataminezhad et al., (2014) and Al-Humam (2016).

All thirty isolates were subjected for morphological and biochemical studies. Morphological studies comprise colony and cell morphology. With respect to colony morphology, eight isolates had irregular (TS1, TW-2, DWH-2, HW-1, HW-2, HS-2, HC-2 and HS-1) and 22 isolates (TJ-1, TJ-2, DW-1, DW-2, DW-3, DB-1, DB-2, KJ-1, KS-1, KS2, SS-1, SS-2, SSF-1, TW-1, DWH-1, HW-3, HS-1, HS-3, HC-1, HS-2, UW-1 and UW-2) produced circular shaped colonies. Out of 30 isolates, six isolates (TJ-2, SS-1, DWH-1, HS3, HC-2 and HS-1) formed creamy white coloured colonies and twenty four isolates (TS-1, TJ-1, DW-1, DW-2, DW-3, DB-1, DB2, KJ-1, KS-1, KS-2, SS-2, SSF-1, TW-1, TW-2, DWH-2, HW-1, HW-2, HW-3, HS-1, HS-2, HC-1, HS-2, UW-1 and UW-2) formed white coloured colonies. Diameter of the colonies ranged from 3-8 $\mathrm{mm}$. The colonies formed by all the isolates were rough with wavy margin. With respect to cell morphology, the size of the cells ranged from $2.5 \times 1.0 \mu \mathrm{m}$ to $5.5 \times 1.5 \mu \mathrm{m}$. All the isolates subjected for gram staining showed gram positive for the reaction. All the isolates formed endospores (Table 1).

With respect to biochemical characterization, all the isolates showed positive for catalase test, nitrate reduction, V-P test and oxidase test and negative for acid and gas production, arginine hydrolysis, esterase activity and chitinase activity. Out of 30 isolates, 26 
isolates showed positive for starch hydrolysis. All the isolates, except three (DWH-2, HW-2 and $\mathrm{HC}-1)$ showed positive for casein hydrolysis (Table 2).

The isolates were identified using Gram staining, catalase test, motility, starch hydrolysis, Voges Proskauer, citrate utilizations tests, endospore staining, and haemolysis test. The isolates were subjected to confirmatory test to the genus level (AlHumam, 2016). Similarly Parvati et al. (2009) used nitrate reduction, anaerobic growth, gas production from glucose, Voges Proskauer (VP), growth at different $\mathrm{NaCl}$ concentrations, temperature and $\mathrm{pH}$ ranges, acid production from arabinose, mannitol, xylose, glucose, lactose, citrate utilization and production of DNAse for the characterization of Bacillus pumilus isolated from coastal environment in Cochin, India.

Further, all the isolates were subjected for functional characterization viz., Psolubilization efficiency and PGPS production (IAA and GA). All the 30 isolates (TS-1, TJ-1, TJ-2, DW-1, DW-2, DW-3, DB-1, DB-2, KJ1, KS-1, KS-2, SS-1, SS-2, SSF-1, TW-1, TW-2, DWH-1, DWH-2, HW-1, HW-2, HW3, HS-1, HS-2, HS-3, HC-1, HC-2, HS-1, HS2, UW-1 and UW-2) showed zone of solubilization on Pikovskaya's media, which indicate the efficiency of the isolates to solubilize the inorganic phosphorous. The zone of solubilization $(\mathrm{mm})$ ranged from 7.2 to $16.00 \mathrm{~mm}$ on the petriplate. The isolates KJ-1, HS-1 and HC-1 showed the maximum zone of solubilization of $16.00,15.10$ and $14.50 \mathrm{~mm}$ respectively. Minimum zone of $\mathrm{P}$ solubilization of 7.0, 7.2, 7.5 and $7.8 \mathrm{~mm}$ was recorded by the isolates DW-1, HC-2, DWH-2 and TW-2 respectively. Further, quantitative estimation of Pi released in the media was also estimated. Amount of Pi released was in the range of 4.7 to 13.70 per cent. The maximum amount of Pi released in TCP broth was 13.7 $\%$ by the isolate $\mathrm{KJ}-1$, which was followed by
13.2 and 12.6 per cent by the isolates HS-1 and $\mathrm{HC}-1$ respectively. Less amount of $\mathrm{Pi}$ was released by DWH-2 and HC-2 with 4.2 and 4.7 per cent respectively. The isolates SS-1, TW-1 and TW-2 released 5.2 per cent Pi in the TCP broth. Several scientists have reported the ability of different bacterial species to solubilize insoluble inorganic phosphate compounds, such as tricalcium phosphate, dicalcium phosphate, hydroxyapatite, and rock phosphate (Pikovskaya, 1948).

All 30 isolates were also tested for IAA and GA production. Out of 30 isolates, only 10 isolates (TS-1, TJ-2, DW-2, KJ-1, KS-2, SSF1, TW-1, DWH-1, HS-1 and HC-1) were positive for IAA and GA production (Table 1).

IAA production in the isolates ranged from 6.20 to $10.12 \mu \mathrm{g} / 25 \mathrm{ml}$. The maximum IAA production of $10.12 \mu \mathrm{g} / 25 \mathrm{ml}$ was recorded in the isolate $\mathrm{HC}-1$ followed by the isolate DW-2 $(9.60 \mu \mathrm{g} / 25 \mathrm{ml})$. The lowest IAA production of $6.20 \mu \mathrm{g} / 25 \mathrm{ml}$ was observed in the isolate SSF-1.

GA production in the isolates ranged from 1.00 to $3.17 \mu \mathrm{g} / 25 \mathrm{ml}$. The highest GA production was recorded in the isolate HS-1 $(3.17 \mu \mathrm{g} / 25 \mathrm{ml})$ followed by the isolate $\mathrm{KJ}-1$ $(3.15 \mu \mathrm{g} / 25 \mathrm{ml})$. The least GA production was recorded in the isolate TS-1(1.00 $\mu \mathrm{g} / 25 \mathrm{ml})$. Many phosphate solubilizing bacteria are reported as plant growth promoter (Hafeez, 2004; Katiyar and Goel, 2003; Rodríguez and Fraga, 1999). It is well established that introduction of plant growth promoting bacteria (PGPB) in soil improves the plant growth. PGPB promote plant growth through the production of plant growth hormones (Patten and Glick, 2002; Bottini et al., 2004).

A large proportion (80\%) of bacteria colonizing the rhizosphere have been reported positive for IAA production, but reports depicting IAA production by Gram-positive soil-living bacteria are only few (Loper and 
Schroth, 1986). However, Idris et al. (2004) showed production of substances with auxin (IAA)-like bioactivity from strains of $B$. subtilis/B. amyloliquefaciens including strain FZB42. Further, gibberellins production was confirmed from $B$. pumilus and $B$. licheniformis (Gutierrez-Manero et al., 2001).

Based on the ability of the isolates to solubilise inorganic phosphorous and IAA and GA production, ten of the isolates (TS-1, TJ-2, DW-2, KJ-1, KS-2, SSF-1, TW-1, DWH-1, HS-1 and HC-1) were taken for pot culture experiment using sorghum as test crop.

Plant growth promotional activity of Bacillus strains in sorghum

Result on effect of different Bacillus strains on plant height of sorghum were recorded at 30 , 60 and 90 days after sowing and are presented in Table 3.

Non significant differences were observed at 30 DAS with respect to plant height of sorghum. At 60 DAS, the highest plant height of $83.15 \mathrm{~cm}$ was recorded by the treatment $\mathrm{T} 4$ (KJ-1 isolate) $(91.3 \mathrm{~cm})$, which is on par with the treatments T8 (DWH-1), T11 (reference strain) and T9 (HS-1). Least plant height was observed in T12-control $(68.30 \mathrm{~cm})$.

At 90 DAS, Highest plant height of $175.00 \mathrm{~cm}$ was observed in treatment T4 (KJ-1 isolate), which is on par with the treatments T11 (reference strain) $(174.00 \mathrm{~cm})$ and T8 (DWH1) $(172.00 \mathrm{~cm})$, and $\mathrm{T} 9(\mathrm{HS}-1)$. Least plant height was observed in T12-control (150.00 $\mathrm{cm})$.

The pronounced plant growth by PGPRs observed in the present study can be attributed to the production of IAA, IBA and solubilization of phosphate. Such findings are in agreement with many authors who reported phytohormones production by Pseudomonas (Glick, 1995).
Result on effect of different Bacillus strains on shoot dry matter content and root dry matter content was recorded at 30,60 and 90 days after sowing and are presented in Table 4.

At 30 DAS, highest shoot dry weight of $4.0 \mathrm{~g}$ was recorded by the treatment T9 (HS-1) and T11 (Reference strain), which were significantly on par with T8 (DWH-1) (3.79 g). Least shoot dry weight of $1.98 \mathrm{~g}$ was recorded in $\mathrm{T} 7$ (TW-1).

At 60 DAS, significantly highest shoot dry weight of $9.05 \mathrm{~g}$ was recorded in T4 (KJ-1), which was on par with T11 (Reference strain) $(9.00 \mathrm{~g})$ and T8 (DWH-1) (8.76 g). Lowest shoot dry weight of $6.70 \mathrm{~g}$ was recorded in T12 (control).

At 90 DAS, significantly highest shoot dry weight of $32.02 \mathrm{~g}$ was recorded in T11 (Reference strain), which was on par with $\mathrm{T} 4$ $(\mathrm{KJ}-1)(30.08 \mathrm{~g})$. Least shoot dry weight of $25.05 \mathrm{~g}$ was recorded in T12 (control).

Insignificant results were observed with respect to root dry weight of plant at 30 DAS. At 60 DAS, highest root dry weight of $4.0 \mathrm{~g}$ was recorded in T4 (KJ-1), which was on par with T8 (DWH-1) (3.80 g) and T9 (HS-1) $(3.75 \mathrm{~g})$.

At 90 DAS, highest root dry weight was recorded in T4 (KJ-1) $(5.10 \mathrm{~g})$, which was on par with T8 (DWH-1) $(4.80 \mathrm{~g})$ and T11 (reference strain) $(4.75 \mathrm{~g})$. Enhancement of plant growth by root colonizing species of Bacillus and Paenibacillus is well known (Idris et al., 2007; Kloepper et al., 2004). It is also very likely that growth promoting effects of various PGPRs are due to bacterial production of plant growth regulators such as indole-3-acetic acid (IAA), gibberellins, and cytokinins (Bottini et al., 2004; Bloemberg and Lugtenberg, 2001). 
Table.1 Morphological characterization of Bacillus isolates

\begin{tabular}{|c|c|c|c|c|c|c|c|c|c|c|}
\hline \multirow{2}{*}{$\begin{array}{l}\text { Sl. } \\
\text { No. }\end{array}$} & \multicolumn{6}{|c|}{ Colony morphology } & \multicolumn{4}{|c|}{ Cell morphology } \\
\hline & $\begin{array}{c}\text { Isolate } \\
\text { No. }\end{array}$ & Shape & Colour & $\begin{array}{c}\text { Size } \\
\text { Dia. }(\mathrm{mm})\end{array}$ & Nature & Margin & $\begin{array}{c}\text { Size }(\mu \mathrm{m}) \\
(\mathbf{L x B})\end{array}$ & Shape & $\begin{array}{c}\text { Gram } \\
\text { reaction }\end{array}$ & $\begin{array}{l}\text { Endospore } \\
\text { formation }\end{array}$ \\
\hline 1. & TS-1 & Irregular & White & 6 & Rough & Wavy & $3.0 \times 1.0$ & Rods & G+ve & + \\
\hline 2. & TJ-1 & Circular & White & 3 & Rough & Wavy & $3.5 \times 1.5$ & Rods & $\mathrm{G}+\mathrm{ve}$ & + \\
\hline 3. & TJ-2 & Circular & Creamy white & 6 & Rough & Wavy & $3.0 \times 1.0$ & Rods & $\mathrm{G}+\mathrm{ve}$ & + \\
\hline 4. & DW-1 & Circular & White & 8 & Rough & Wavy & $2.5 \times 1.0$ & Rods & G+ve & + \\
\hline 5. & DW-2 & Circular & White & 8 & Rough & Wavy & $5.5 \times 1.5$ & Rods & G+ve & + \\
\hline 6. & DW-3 & Circular & White & 6 & Rough & Wavy & $4.0 \times 1.0$ & Rods & G+ve & + \\
\hline 7. & DB-1 & Circular & White & 7 & Rough & Wavy & $5.0 \times 1.5$ & Rods & $\mathrm{G}+\mathrm{ve}$ & + \\
\hline 8. & DB-2 & Circular & White & 8 & Rough & Wavy & $5.5 \times 1.5$ & Rods & G+ve & + \\
\hline 9. & KJ-1 & Circular & White & 3 & Rough & Wavy & $4.5 \times 1.5$ & Rods & G+ve & + \\
\hline 10. & KS-1 & Circular & White & 7 & Rough & Wavy & $5.0 \times 1.5$ & Rods & $\mathrm{G}+\mathrm{ve}$ & + \\
\hline 11. & $\mathrm{KS}-2$ & Circular & White & 3 & Rough & Wavy & $3.5 \times 1.5$ & Rods & $\mathrm{G}+\mathrm{ve}$ & + \\
\hline 12. & SS-1 & Circular & Creamy white & 6 & Rough & Wavy & $4.5 \times 1.5$ & Rods & G+ve & + \\
\hline 13. & SS-2 & Circular & White & 8 & Rough & Wavy & $5.5 \times 1.5$ & Rods & G+ve & + \\
\hline 14. & SSF-1 & Circular & White & 4 & Rough & Wavy & $5.0 \times 1.0$ & Rods & $\mathrm{G}+\mathrm{ve}$ & + \\
\hline 15. & TW-1 & Circular & White & 7 & Rough & Wavy & $3.5 \times 1.5$ & Rods & $\mathrm{G}+\mathrm{ve}$ & + \\
\hline 16. & TW-2 & Irregular & White & 3 & Rough & Wavy & $3.0 \times 1.0$ & Rods & G+ve & + \\
\hline 17. & DWH-1 & Circular & Creamy white & 4 & Rough & Wavy & $3.0 \times 1.0$ & Rods & G+ve & + \\
\hline 18. & DWH-2 & Irregular & White & 6 & Rough & Wavy & $5.5 \times 1.5$ & Rods & G+ve & + \\
\hline 19. & HW-1 & Irregular & White & 5 & Rough & Wavy & $3.5 \times 1.5$ & Rods & $\mathrm{G}+\mathrm{ve}$ & + \\
\hline 20. & HW-2 & Irregular & White & 5 & Rough & Wavy & $3.0 \times 1.5$ & Rods & $\mathrm{G}+\mathrm{ve}$ & + \\
\hline 21. & HW-3 & Circular & White & 7 & Rough & Wavy & $2.5 \times 1.0$ & Rods & $\mathrm{G}+\mathrm{ve}$ & + \\
\hline 22. & HS-1 & Circular & White & 6 & Rough & Wavy & $6.0 \times 1.5$ & Rods & $\mathrm{G}+\mathrm{ve}$ & + \\
\hline 23. & HS-2 & Irregular & White & 5 & Rough & Wavy & $4.5 \times 1.0$ & Rods & G+ve & + \\
\hline 24. & HS-3 & Circular & Creamy white & 7 & Rough & Wavy & $4.5 \times 1.5$ & Rods & $\mathrm{G}+\mathrm{ve}$ & + \\
\hline 25. & HC-1 & Circular & White & 8 & Rough & Wavy & $5.5 \times 1.0$ & Rods & $\mathrm{G}+\mathrm{ve}$ & + \\
\hline 26. & $\mathrm{HC}-2$ & Irregular & Creamy white & 5 & Rough & Wavy & $3.5 \times 1.5$ & Rods & G+ve & + \\
\hline 27. & HS-1 & Irregular & Creamy white & 6 & Rough & Wavy & $3.0 \times 1.0$ & Rods & $\mathrm{G}+\mathrm{ve}$ & + \\
\hline 28. & HS-2 & Circular & White & 4 & Rough & Wavy & $2.5 \times 1.0$ & Rods & $\mathrm{G}+\mathrm{ve}$ & + \\
\hline 29. & UW-1 & Circular & White & 5 & Rough & Wavy & $4.0 \times 1.5$ & Rods & G+ve & + \\
\hline 30. & UW-2 & Circular & White & 6 & Rough & Wavy & $3.5 \times 1.5$ & Rods & G+ve & + \\
\hline
\end{tabular}




\section{Int.J.Curr.Microbiol.App.Sci (2018) 7(12): 628-639}

Table.2 Biochemical characterization of Bacillus isolates

\begin{tabular}{|c|c|c|c|c|c|c|c|c|c|c|c|}
\hline $\begin{array}{l}\text { Sl. } \\
\text { No. }\end{array}$ & $\begin{array}{c}\text { Isolate } \\
\text { Number }\end{array}$ & $\begin{array}{c}\text { Starch } \\
\text { Hydrolysis }\end{array}$ & $\begin{array}{c}\text { Casein } \\
\text { hydrolysis }\end{array}$ & $\begin{array}{l}\text { Acid and } \\
\text { gasprodn. }\end{array}$ & $\begin{array}{c}\text { Nitrate } \\
\text { reduction }\end{array}$ & $\begin{array}{c}\text { V-P } \\
\text { reaction }\end{array}$ & $\begin{array}{c}\text { Catalase } \\
\text { test }\end{array}$ & $\begin{array}{l}\text { Arginine } \\
\text { hydrolysis }\end{array}$ & $\begin{array}{l}\text { Esterase } \\
\text { activity }\end{array}$ & $\begin{array}{l}\text { Chitinase } \\
\text { activity }\end{array}$ & $\begin{array}{c}\text { Oxidase } \\
\text { test }\end{array}$ \\
\hline 1. & TS-1 & + & + & - & + & + & + & - & - & - & + \\
\hline 2. & TJ-1 & + & + & - & + & + & + & - & - & - & + \\
\hline 3. & TJ-2 & + & + & - & + & + & + & - & - & - & + \\
\hline 4. & DW-1 & + & + & - & + & + & + & - & - & - & + \\
\hline 5. & DW-2 & + & + & - & + & + & + & - & - & - & + \\
\hline 6. & DW-3 & - & + & - & + & + & + & - & - & - & + \\
\hline 7. & DB-1 & + & + & - & + & + & + & - & - & - & + \\
\hline 8. & DB-2 & + & + & - & + & + & + & - & - & - & + \\
\hline 9. & KJ-1 & + & + & - & + & + & + & - & - & - & + \\
\hline 10 & KS-1 & + & + & - & + & + & + & - & - & - & + \\
\hline 11. & $\mathrm{KS}-2$ & + & + & - & + & + & + & - & - & - & + \\
\hline 12. & SS-1 & + & + & - & + & + & + & - & - & - & + \\
\hline 13. & SS-2 & + & + & - & + & + & + & - & - & - & + \\
\hline 14. & SSF-1 & + & + & - & + & + & + & - & - & - & + \\
\hline
\end{tabular}


Int.J.Curr.Microbiol.App.Sci (2018) 7(12): 628-639

\begin{tabular}{|c|c|c|c|c|c|c|c|c|c|c|c|}
\hline 15. & TW-1 & + & + & - & + & + & + & - & - & - & + \\
\hline 16. & TW-2 & - & + & - & + & + & + & - & - & - & + \\
\hline 17. & DWH-1 & + & + & - & + & + & + & - & - & - & + \\
\hline 18. & DWH-2 & + & - & - & + & + & + & - & - & - & + \\
\hline 19. & HW-1 & + & + & - & + & + & + & - & - & - & + \\
\hline 20. & HW-2 & + & + & - & + & + & + & - & - & - & + \\
\hline 21. & HW-3 & + & - & - & + & + & + & - & - & - & + \\
\hline 22. & HS-1 & + & + & - & + & + & + & - & - & - & + \\
\hline 23. & HS-2 & + & + & - & + & + & + & - & - & - & + \\
\hline 24. & HS-3 & + & + & - & + & + & + & - & - & - & + \\
\hline 25. & HC-1 & - & - & - & + & + & + & - & - & - & + \\
\hline 26. & HC-2 & + & + & - & + & + & + & - & - & - & + \\
\hline 27. & HS-1 & + & + & - & + & + & + & - & - & - & + \\
\hline 28. & HS-2 & - & + & - & + & + & + & - & - & - & + \\
\hline 29. & UW-1 & + & + & - & + & + & + & - & - & - & + \\
\hline 30. & UW-2 & + & + & - & + & + & + & - & - & - & + \\
\hline
\end{tabular}

+: positive for the test, -: negative for the test 
Int.J.Curr.Microbiol.App.Sci (2018) 7(12): 628-639

Table.3 Functional characterization of native Bacillus isolates

\begin{tabular}{|c|c|c|c|c|c|}
\hline \multirow[t]{2}{*}{ SI. No. } & \multirow[t]{2}{*}{ Isolate No. } & \multicolumn{2}{|c|}{ P-solubilization } & \multirow{2}{*}{$\begin{array}{c}\text { IAA } \\
(\mu \mathrm{g} / 25 \mathrm{ml})\end{array}$} & \multirow{2}{*}{$\begin{array}{c}\text { GA } \\
(\mu \mathrm{g} / 25 \mathrm{ml})\end{array}$} \\
\hline & & $\begin{array}{c}\text { Qualitative } \\
\text { ZoS (mm) }\end{array}$ & $\begin{array}{c}\text { Quantitative } \\
\% \mathbf{P i}\end{array}$ & & \\
\hline 1. & TS-1 & 11.0 & 9.6 & 7.50 & 1.00 \\
\hline 2. & TJ-1 & 8.2 & 6.9 & - & - \\
\hline 3. & TJ-2 & 10.4 & 9.1 & 9.50 & 1.20 \\
\hline 4. & DW-1 & 7.0 & 5.1 & - & - \\
\hline 5. & DW-2 & 12.5 & 10.1 & 9.60 & 1.10 \\
\hline 6. & DW-3 & 9.2 & 8.6 & - & - \\
\hline 7. & DB-1 & 9.1 & 8.6 & - & - \\
\hline 8. & DB-2 & 9.8 & 9.1 & - & - \\
\hline 9. & $\mathrm{KJ}-1$ & 16.0 & 13.7 & 8.50 & 3.15 \\
\hline 10. & KS-1 & 8.7 & 8.2 & - & - \\
\hline 11. & KS-2 & 12.6 & 10.4 & 7.89 & 1.30 \\
\hline 12. & SS-1 & 7.3 & 5.2 & - & - \\
\hline 13. & SS-2 & 9.8 & 8.5 & - & - \\
\hline 14. & SSF-1 & 13.0 & 11.1 & 6.20 & 2.13 \\
\hline 15. & TW-1 & 13.2 & 11.7 & 6.50 & 2.50 \\
\hline 16. & TW-2 & 7.8 & 5.2 & - & - \\
\hline 17. & DWH-1 & 13.2 & 11.5 & 6.23 & 2.20 \\
\hline 18. & DWH-2 & 7.5 & 4.2 & - & - \\
\hline 19. & HW-1 & 8.8 & 7.6 & - & - \\
\hline 20. & HW-2 & 9.0 & 7.9 & - & - \\
\hline 21. & HW-3 & 8.2 & 7.0 & - & - \\
\hline 22. & HS-1 & 15.1 & 13.2 & 8.80 & 3.17 \\
\hline 23. & HS-2 & 9.2 & 8.0 & - & - \\
\hline 24. & HS-3 & 8.6 & 7.2 & - & - \\
\hline 25. & HC-1 & 14.5 & 12.6 & 10.12 & 2.24 \\
\hline 26. & $\mathrm{HC}-2$ & 7.2 & 4.7 & - & - \\
\hline 27. & HS-1 & 7.6 & 5.4 & - & - \\
\hline 28. & HS-2 & 8.4 & 7.3 & - & - \\
\hline 29. & UW-1 & 9.5 & 8.2 & - & - \\
\hline 30. & UW-2 & 8.9 & 7.3 & - & - \\
\hline
\end{tabular}


Table.4 Effect of Bacillus strains on plant height $(\mathrm{cm})$ and dry matter content $(\mathrm{g} / \mathrm{plant})$ of Sorghum

\begin{tabular}{|c|c|c|c|c|c|c|c|c|c|}
\hline \multirow[t]{2}{*}{2} & \multicolumn{3}{|c|}{ Plant height (cm) } & \multicolumn{3}{|c|}{ Shoot dry weight (gm) } & \multicolumn{3}{|c|}{ Root dry weight (gm) } \\
\hline & 30 DAS* & $60 \mathrm{DAS}$ & 90 DAS & 30 DAS & $60 \mathrm{DAS}$ & 90 DAS & $\begin{array}{l}30 \\
\text { DAS }\end{array}$ & 60 DAS & 90 DAS \\
\hline $\mathrm{T}_{1}-\mathrm{TS}-1$ & 29.2 & 68.73 & 162.00 & 2.50 & 8.58 & 27.30 & 1.17 & 2.50 & 3.95 \\
\hline $\mathrm{T}_{2}-\mathrm{TJ}-2$ & 26.9 & 71.56 & 170.00 & 2.20 & 7.09 & 28.50 & 1.05 & 2.30 & 4.25 \\
\hline $\mathrm{T}_{3}-\mathrm{DW}-2$ & 23.9 & 73.13 & 168.00 & 2.17 & 7.20 & 26.80 & 1.07 & 3.20 & 4.30 \\
\hline $\mathrm{T}_{4}-\mathrm{KJ}-1$ & 24.9 & 83.15 & 175.00 & 3.00 & 9.05 & 30.08 & 1.57 & 4.00 & 5.10 \\
\hline $\mathrm{T}_{5}-\mathrm{KS}-2$ & 25.1 & 77.26 & 163.00 & 2.95 & 8.30 & 27.23 & 0.97 & 3.30 & 4.28 \\
\hline $\mathrm{T}_{6}-\mathrm{SSF}-1$ & 24.9 & 75.00 & 170.00 & 2.05 & 7.50 & 27.21 & 1.00 & 2.75 & 4.45 \\
\hline $\mathrm{T}_{7}-\mathrm{TW}-1$ & 27.2 & 77.06 & 165.00 & 1.98 & 7.80 & 26.24 & 1.08 & 2.80 & 4.38 \\
\hline $\mathrm{T}_{8}-\mathrm{DWH}-1$ & 26.00 & 82.00 & 172.00 & 3.75 & 8.76 & 28.31 & 1.00 & 3.80 & 4.80 \\
\hline $\mathrm{T}_{9}-\mathrm{HS}-\mathrm{S}$ & 25.4 & 80.00 & 170.00 & 4.00 & 8.45 & 28.10 & 1.30 & 3.75 & 4.60 \\
\hline $\mathrm{T}_{10}-\mathrm{HC}-1$ & 28.2 & 72.00 & 161.00 & 2.80 & 8.35 & 26.30 & 1.20 & 3.00 & 4.00 \\
\hline $\begin{array}{l}\mathrm{T}_{11}-\mathrm{PSB} \\
\text { (existing) }\end{array}$ & 26.9 & 82.00 & 174.00 & 4.00 & 9.00 & 32.02 & 1.47 & 3.70 & 4.75 \\
\hline $\mathbf{T}_{12}-$ Control & 18.5 & 68.30 & 150.00 & 2.00 & 6.70 & 25.05 & 0.9 & 2.00 & 3.90 \\
\hline S.Em \pm & 1.27 & 1.39 & 1.18 & 0.12 & 0.21 & 0.83 & 0.09 & 0.10 & 0.13 \\
\hline CD (0.01) & NS & 3.92 & 3.34 & 0.33 & 0.59 & 2.35 & 0.26 & 0.29 & 0.36 \\
\hline
\end{tabular}

*DAS- days after sowing

In conclusion, our dependence on chemical fertilisers and pesticides has encouraged the thriving of industries that are producing lifethreatening chemicals and which are not only hazardous for human consumption but can also disturb the ecological balance. Biofertilizers can help solve the problem of feeding an increasing global population at a time when agriculture is facing various environmental stresses. The success of the science related to biofertilizers depends on inventions of innovative strategies related to the functions of PGPRs and their proper application to the field of agriculture. The major challenge in this area of research lies in the fact that along with the identification of various strains of PGPRs and its properties it is essential to dissect the actual mechanism of functioning of PGPRs for their efficacy toward exploitation in sustainable agriculture.

\section{References}

Al-Humam, N. A. 2016. Heat-shock technique for isolation of soil Bacillus species with potential of antibiotics secretion in Saudi Arabia. British Microbiology Research Journal. 17(3):1-6.

Anonymous. 1957. Manual of microbiological methods, McGraw Hill Book Company Inc., New York, pp. 127.

Barthalomen, J.W. and Mittewar, T. 1950. A 
simplied bacterial stain. Stain Tech., 25: 153.

Bloemberg, G.V. and Lugtenberg B.F.J. 2001. Molecular Basis of plant growth promotion and biocontrol by rhizobacteria. Curr. Opin. Plant Biol. 4:343-350.

Bottini, R., Cassan, F. and Picolli, P. 2004. Gibberellin production by bacteria and its involvement in plant growth promotion. Appl. Microbiol. Biotechnol., 65:497-503.

Cappuccino, J. G. and Sherman, N. 1992. Microbiology: A Laboratory Manual, The Benjamin/Cummins Publishing Company Inc., California.

Chan, K. G., Tuew, S.Z. and Ng, C.C. 2007. Rapid isolation method of soil bacilli and screening of their quorum quenching activity. Asia pacific Journal of Molecular Biology \& Biotechnology. 15 (3):153-156.

Glick, B. R., 1995. The enhancement of plant growth by free-living bacteria. Can. J. Microbiol., 41:109-117.

Gutierrez-Manero, F. J., Ramos, B., Probanza, A., Mehouachi, J. and Talon, M. 2001, The plant growth promoting rhizobacteria Bacillus pumilus and Bacillus licheniformis produce high amounts of physiologically active gibberelins. Physiol. Plant. 111:206211.

Rodríguez, H. and Fraga, R. 1999. Phosphate solubilizing bacteria and their role in plant growth promotion. Biotechnology Advances. 17: 319- 339.

Hafeez, F. Y., Safdar, M. E., Chaudhry, A. U. and Malik, K. A. 2004. Rhizobial inoculation improves seedling emergence, nutrient uptake and growth of cotton. Australian Journal of Experimental Agriculture. 44(6):617622.

Hurek, T. and Reinhold-Hurek, B. 2003. Azoarcus spp. strain BH72 as a model for nitrogen fixing grass endophytes. J. Biotechnol., 106:169.

Idris, E.E.S., Bochow, H., Ross, H. and Boriss, R. 2004. Use of Bacillus subtilis as biocontrol agent. VI. Phytohormonelike action of culture filtrate prepared from plant growth promoting Bacillus amyloliquefaciens FZB24, FZB42, FZB45 and Bacillus subtilis FZB37. J. Plant. Dis. Prot., 111:583-597.

Idris, E. E. S., Iglesias, D. J., Talon, M. and Borriss, R. 2007. Tryptophan-dependent production of Indole-3- Acetic Acid (IAA) affects level of plant growth promotion by Bacillus amyloliquefaciens FZB42. Mol. Plant Microbe Interact., 20:619-626.

Katiyar, V. and Goel, R. 2003. Solubilization of inorganic phosphate and plant growth promotion by cold tolerant mutants of Pseudomonas fluorescens. Microbiol Res. 158:163-168.

Khataminezhad, M. R., Ashrafalsadat, N., Razavi, M. Reza., Taher, N. and Nazemi Ali. 2014. Isolation and molecular identification of extracellular lipase-producing Bacillus species from soil. Annals of Biological Research. 5 (1):132-139.

Kloepper, J. W., Ryu, C.M. and Zhang, S. 2004, Induced systemic resistance and promotion of plant growth by Bacillus spp. Phytopathology. 94:1259-1266.

Loper, J. E. and Schroth, M. N. 1986. Influence of bacterial sources of indole3 -acetic acid biosynthetic on root elongation of sugar beet. Phytopathology. 76:386-389.

Matthysse, A.G., Marry, M., Krall, L., Kaye, M., Ramey, B.E., Fuqua, C. and White, A.R. 2005. The effect of cellulose overproduction on binding and biofilm formation on roots by Agrobacterium tumefaciens. Molecular Plant Microbe Interactions. 18: 1002-1010.

Michiels, K.W., Croes, C. L. and 
Vanderleyden, J. 1991. Two different modes of attachment of Azospirillum brasilense Sp7 to wheat roots. J. Gen. Microbiol., 137:2241-2246.

Nadeem, S.M., Zahir, Z.A., Naveed, M. and Arshad, M. 2007. Preliminary investigations on inducing salt tolerance in maize through inoculation with rhizobacteria containing ACC deaminase activity. Can. J. Microbiol., 53: 1141-1149.

Patten, C. L. and Glick, B. R. 2002. Role of Pseudomonas putida indole-acetic acid in development of host plant root system. Appl. Environ. Microbiol., 68:3795-3801.

Parvathi, A., Krishna, K., Jose, J., Joseph, N. and Nair, S. 2009. Biochemical and molecular characterization of Bacillus pumilus isolated from coastal environment in Cochin, India. Braz. J. Microbiol., 40: 269-275.

Pikovaskya, R. E. 1948. Mobilization of phosphorous in soil in connection with vital activity of some microbial species. Mikrobiological. 17:362-370.

Ramey, B.E., Matthysse, A.G. and Fuqua, C. 2004. The FNR-type transcriptional regulator SinR controls maturation of Agrobacterium tumefaciens biofilms. Mol. Microbiol., 52:1495-1511.
Richardson, A. E., Baréa, J. M., McNeill, A. M. and Prigent-Combaret, C. 2009. Acquisition of phosphorus and nitrogen in the rhizosphere and plant growth promotion by microorganisms. Plant Soil. 321: 305-339.

Sivasakthi, S., Kanchana, D., Usharani, G. and Saranraj, P. 2013. Production of plant growth promoting substance by Pseudomonas fluorescens and Bacillus subtilis isolated from paddy rhizosphere soil of Cuddalore district, Tamil Nadu, India. International Journal of Microbiological Research. 4(3): 227 233.

Wahyudi, A. T., Astuti, R. P., Widyawati, A., Meryandini, A. and Nawangsih, A. A. 2011, Characterization of Bacillus sp. strains isolated from rhizosphere of soybean plants for their use as potential plant growth for promoting Rhizobacteria. Journal of Microbiology and Antimicrobials. 3(2): 34-40.

Zahir, Z.A., Munir, A., Asghar, H. N., Shaharoona, B. and Arshad, M. 2008. Effectiveness of rhizobacteria containing ACC-deaminase for growth promotion of pea (Pisum sativum) under drought conditions. J. Microbiol. Biotechnol., 18: 958-963.

\section{How to cite this article:}

Geeta Goudar, G. Sreenivasulu and Krishnaraj, P.U. 2018. Evaluation of Bacillus Strains Isolated from Doni River Belt of Vijayapura District for their Plant Growth Promotional Activity. Int.J.Curr.Microbiol.App.Sci. 7(12): 628-639. doi: https://doi.org/10.20546/ijcmas.2018.712.078 